ИЗВЕСТИЯ АКАДЕМИИ НАУК ЭСТОНСКОП ССР. ТОМ 28 Химия. 1979, № 3

\title{
СИНТЕЗ 3,7,10,11-ТЕТРАМЕТИЛ-2,6,10-ДОДЕКАТРИЕН-1-ОЛА И ЕГО АЦЕТАТА ИЗ ТЕЛОМЕРА ИЗОПРЕНА С ГИДРОХЛОРИДОМ ДИМЕТИЛБУТАДИЕНА
}

K. LAATS, A. KOGERMAN, Kadri AMMON, I. KUDRJAVTSEV. 3,7,10,11-TETRAMETUOL-2,6,10-DODEKATRIEEN-1-OOLI JA TEMA ATSETAADI SONTEES ISOPREENI JA DIMETOULBUTADIEENI HODROKLORIIDI TELOMERISATSIOONIPRODUKTIDEST

K. LAATS, A. KOGERMAN, Kadri AMMON, I. KUDRYAVTSEV. SYNTHESIS OF 3,7,10,11-TETRAMETHYL-2,6,10-DODECATRIEN-1-OL AND ITS ACETATE FROM TELOMERIZATION PRODUCTS OF ISOPRENE WITH HYDROCHLORIDE OF 2,3-DIMETHYLBUTADIENE

Известна реакция теломеризации изопрена с гидрохлоридом диметилбутадиена [']. Из первичного аддукта этого теломера был ранее выделен 6-метил-геранилхлорид, и на основе последнего разработан способ синтеза ценного душистого вещества - ирона. Недавно были выделены также 6-метиллиналоол и 4-метил-2-терпинеол $\left[{ }^{2}\right]$. Однако до сих пор ничего неизвестно о составе высших аддуктов этого теломера.

В настоящей работе мы изучили возможность селективного химического выделения хлоридов с первичной аллильной структурой из высших аддуктов этого теломера по способу [3].

Путем воздействия N, N-диметиланилина на высшие аддукты этого теломера, представляющие смесь изомерных метилированных сесквитерпеновых ди- и тритерпеновых хлоридов, были селективно превращены в четвертичные аммониевые соли хлориды с первичной аллильной структурой:

$\mathrm{C}_{6} \mathrm{H}_{11}\left(\mathrm{C}_{5} \mathrm{H}_{8}\right)_{2-4} \cdot \mathrm{Cl}+\underbrace{\mathrm{N}}_{\mathrm{H}_{3}} \longrightarrow \mathrm{C}_{6} \mathrm{H}_{11}\left(\mathrm{C}_{5} \mathrm{H}_{8}\right)_{2-4}-\mathrm{Cl}_{\mathrm{CH}_{3}}^{\mathrm{CH}_{3}}$

Полученные четвертичные аммониевые соли затем превращались под действием уксуснокислого калия в ацетаты метилированных терпеноидных спиртов $\left[{ }^{4,5}\right]$. Вакуумной разгонкой была выделена узкокипящая фракция ацетата спирта $\mathrm{C}_{16} \mathrm{H}_{28} \mathrm{O}$. Омылением этой фракции был получен спирт. Небольшой образец полученного спирта был окислен хромовым ангидридом в альдегид. Из альдегида получен семикарбазон, температура плавления которого оказалась равной описанной в литературе для семикарбазона 10 -метилфарнезаля $\quad(3,7,10,11$-тетраметил- $2,6,10$-додекатрен-1-аля) [ $\left.{ }^{6}\right]$. Полученные результаты дают основание приписать полученному спирту строение 10-метилфарнезола $(3,7,10,11$-тетраметил- 
2,6,10-додекатриен-1-ола), а ацетату - строение 10-метилфарнезилацетата. Газовая хроматография синтезированного 10-метилфарнезола показала, что он является смесью цис-транс-изомеров. Необходимо отметить, что ввиду приятного запаха эти соединения могут представлять интерес для парфюмерии.

\section{Экспериментальная часть}

В качестве исходного сырья использовали теломер гидрохлорида диметилбутадиена с изопреном, полученный по методике, описанной ранее [']. Фракция хлоридов $\mathrm{C}_{11}$ была выделена из теломера вакуумной перегонкой при $70-95{ }^{\circ} \mathrm{C}$ (2 м.м рт. ст.). Кубовый остаток, который в основном состоял из хлорндов $\mathrm{C}_{16-31}$, содержал 25,6\% 10-метилфарнезилхлорида.

K кубовому остатку (300 2) было добавлено 90 г N, N-диметиланилина и 90 г метанола. Смесь выдерживалась при комнатной температуре 24 ч. Затем ее разбавляли петролейным эфиром, и образовавшиеся четвертичные соли аммония растворяли в $60 \%$-ном водном метаноле. Метанольную вытяжку промывали петролейным эфиром и затем метанол отгоняли в небольшом вакууме при температуре бани не выше $40^{\circ}$. При насыщении оставшегося в колбе водного раствора кристаллическим поташем высаливалась четвертичная аммониевая соль, которая отделялась от водного слоя, затем растворялась в толуоле и сушилась над прокаленным поташем. Затем толуол отгонялся в вакууме вместе с остатками влаги. Выделенные сухие четвертичные аммониевые соли (146,5 z) растворялись в безводном ацетоне (400 z) и добавлялось 69 г свежепрокаленного измельченного уксуснокислого калия. Смесь перемешивалась при комнатной температуре до исчезновения из ацетонового раствора ионов хлора (20 ч). Осадок отфильтровывали и промывали ацетоном. Промывной ацетон присоединяли к основному раствору и затем ацетон удаляли отгонкой в небольшом вакууме. Остаток в колбе нагревали в более глубоком вакууме $\left(5-10\right.$ мм) при температуре $110-115^{\circ}$, при этом отгонялся диметиланилин. Остаток охлаждали, разбавляли петролейным эфиром и промывали $5 \%$-ной $\mathrm{H}_{2} \mathrm{SO}_{4}$, затем раствором $\mathrm{NaHCO}_{3}$ и водой и высушивали прокаленным поташем. После отгонки петролейного эфира остаток (51 2) был перегнан в вакууме. Была выделена фракция в количестве 25,2 г (выход $37,5 \%$ в пересчете на содержавшийся в теломере 10 -метилфарнезилхлорид): т. кип. $133-142 / 2 ; n_{D}^{20} 1,4819$.

Полученная фракция была затем омылена путем 4-часового кипячения на водяной бане с $10 \%$-ным водно-метанольным раствором КОН. Реакционная смесь была разбавлена водой, продукт омыления извлечен эфиром. Эфирная вытяжка промывалась водой до нейтральной реакции, высушивалась над $\mathrm{MgSO}_{4}$, и затем эфир отгонялся. Остаток (22 z) был перегнан в вакууме при 1 мм рт. ст. Была получена фракция 10-метилфарнезола: т. кип. $128-130,5^{\circ} ; n_{D}^{20} 1,4882 ;$ в количестве 16,1 г. Найдено, \%: С 81,$61 ; \mathrm{H} 11,88$. Вычислено, \%: $\left(\mathrm{C}_{16} \mathrm{H}_{28} \mathrm{O}\right)$ С 81,29; $\mathrm{H} 11,94$.

Окисление10-метилфарнезола в 10-метилфарнезаль. 3 г полученного 10-метилфарнезола было окислено двухромистым калием по методике, описанной в [6]. Получено 0,4 а 10-метилфарнезаля. Т. кип. $121-125 / 1 ; n_{D}^{20} 1,4952 ;$ найдено, \%: С 81,$70 ;$ Н 11,$05 ;$ для $\mathrm{C}_{16} \mathrm{H}_{26} \mathrm{O}$ вычислено, \%: С 81,99; Н 11,18; семикарбазон - т. кип. $131-132^{\circ}$ (получен трехкратной перекристаллизацией из спирта). По литературным данным [ ${ }^{6}$, т. пл. семикарбазона $133,5^{\circ}$.

\section{Вывод}

Синтезированы метилфарнезилацетат и 10-метилфарнезол на основе теломера изопрена с гидрохлоридом диметилбутадиена. 


\section{Л И Т Е РА Т У Р А}

1. Белов В. Н., Д а ев Н. А., Кустова С. Д., Л ээтс К. В., Поддубная С. С., Скворцова Н. И., Шепеленкова Е. И., Шумейко А. К. Новый синтез ирона. - ЖОХ, 1957, т. 27, с. 1384-1389.

2. Л ээт с K., Ка ал Т., Линд с а а А. Метилированные терпеновые спирты из теломера изопрена с гидрохлоридом диметилбутадиена. - Изв. АН ЭССР. Хим. Геол., 1975, т. 24 , № 4, с. $303-305$.

3. Лээтс К. В., Когерман А. П., Кудрявцев И. Б., Т аммару У. Э., Р ан г Х. А., Кра а в Л. П. Способ выделения $\beta$-непредельных первичных хлоралкилов. Авт. свид. СССР № 582241. - Бюл. изобретений, 1977, № 44.

4. Л ээтс К. В. Способ получения сложных эфиров замещенных первичных аллиловых спиртов. Авт. свид. СССР № 130042. - Бюл. изобретений, 1960, № 14.

5. Л ээт С К., Қогерм а А. Получение гераниола и фарнезола на базе теломера изопрена с его гидрохлоридами. - Изв. АН ЭССР. Хим. Геол., 1968, т. 17, № 4, c. $368-373$.

6. Ск во рцо в а Н. И., Т ок а рев а В. Я., Белов В. Н. Синтез неролидола, метилнеролидола, фарнезаля и метилфарнезаля. - ЖОХ, 1959, т. 29, вып. 9, c. $3113-3117$.

Институт химии

Академии наук Эстонской ССР
Поступила в редакцию 23/XI 1978 